\title{
Ontogeny and sexual dimorphism in the Middle/Late Devonian rhomboentomozoid ostracod Franklinella
}

\author{
EWA OLEMPSKA \\ Institute of Paleobiology, Polish Academy of Sciences, 00-818 Warszawa, ul. Twarda 51/55, Poland.
}

\begin{abstract}
A large number of three-dimensionally preserved, pyritized specimens of different instars of the rhomboentomozoid ostracod Franklinella (Franklinella) lysogorensis n. sp. were recovered from a mudstone of the Givetian/Frasnian transition beds at Wzdół in the Holy Cross Mountains, Poland. Seven growth stages are identified. Sexual dimorphism is manifested by differences of ribbing pattern in adults. Within the superfamily Entomozoacea, the presence of two types of sexual dimorphism is suggested: ornamental in rhomboentomozoids and domiciliar in entomoprimitiids. Formerly poorly known morphological features of the rhomboentomozoids, including the anteroventral indentation and a contact list ornamented by fine striation, are described. J. Micropalaeontol. 21(1): 9-16, May 2002.
\end{abstract}

\section{INTRODUCTION}

The rhomboentomozoids are a poorly known group of ostracods traditionally assigned to the superfamily Entomozoacea. They usually co-occur with entomozoids, in strata ranging from the Early Devonian to Early Carboniferous throughout the world. They are similar to the entomozoids in having so-called 'fingerprint' ornament but differ in their sub-rectangular lateral outline, straight dorsal margin and presence of spines. Myodocope affinities were proposed for rhomboentomozoids (see Sylvester-Bradley, 1961) but this is controversial (Siveter \& Vannier, 1990).

More than twenty Franklinella species are known from the Middle Devonian to Lower Carboniferous strata from Europe, China, and North America, where they have proved useful in biostratigraphy. Since the work of Rabien (1954, 1956), the biostratigraphical value of Franklinella species in the Late Devonian is undisputed. They are documented mostly from basinal marine environments. Entomozoids and rhomboentomozoids are generally considered to have been predominantly pelagic ostracods (Gooday, 1983; Bless et al., 1986; Becker \& Bless, 1990; Olempska, 1992, 1997, 1998; Lethiers \& Whatley, 1994), however, a benthic mode of life has also been advocated (Warshauer \& Duffield, 1983; Casier, 1987). Although rhomboentomozoids are geographically widespread, diverse and numerous, little is known about their morphology and ontogeny. The internal morphology of their shells remains unknown; the available material is typically limited and often badly and incompletely preserved. Their shells are poorly calcified and fragile, and most material occurs as poorly preserved compressed moulds.

The possible presence of sexual dimorphism in entomozoids arose when Richter (1869) distinguished spherical and oval forms in Richteria serratostriata (Sandberger, 1845), Rabienella barrandei (Richter, 1869), and Richterina (Fossirichterina) costata (Richter, 1869). He believed that these were sexual dimorphs. This view was followed by Rzehak (1881), who also recognized oval and spherical (sexual) dimorphs in Richterina (Richterina) striatula (Richter, 1848), and Richterina (Fossirichterina) moravica (Rzehak, 1881). Paeckelmann (1913), while acknowledging differences in the outline of specimens of $R$. (R.) striatula, concluded that they do not form separate dimorphs. Rabien (1954) and Gooday (1973) also concluded that these morphotypes had no dimorphic significance and they interpreted them to result from tectonic deformation.

A different view was taken by Gozalo (1994), who noticed different types of ornamentation of the shell of Franklinella (Arnoldella) trispinosa (Gozalo, 1994) from the Frasnian of the Tabuenca-Rodanas area, Spain. He, was, therefore, the first to demonstrate the presence of dimorphs (tecnomorphs and heteromorphs) in rhomboentomozoids.

Sexual dimorphism was probably widespread also in typical entomozoids. Recently, Orlov (1996) recognized heteromorphs with a swollen posterior part of the carapace in several genera of Entomoprimitiinae Gründel, 1962, thus suggesting the presence of sexual dimorphism of domiciliar type (entomoprimitiine type according to Orlov, 1996).

\section{MATERIAL}

Abundant specimens of Franklinella, representing the new species $F$. $(F$.) lysogorensis, occur in mudstones and marls of the Givetian/Frasnian boundary beds (sample Wz R-Ic/2) at Ściegnia village in the Holy Cross Mountains, Poland (Wzdół Plebański section; Fig. 1). The ostracods are associated with a dominantly nectopelagic fauna of dacryoconariids and ammonoids (Racki, in prep.).

Preservation of the ostracod shells at Wzdó is variable. In general, they are preserved as moulds, but a few samples yielded undeformed, pyritized specimens. The pyritized specimens are preserved mostly as closed or half open carapaces. The material studied consists of about 200 pyritized carapaces and thousands of moulds. Moulds of disarticulated valves of $F$. $(F$.) lysogorensis are almost always strongly deformed, thus increasing the height of the valve in relation to its length; such specimens were not measured.

Rare specimens of Waldeckella, co-occurring with $F$. (F.) lysogorensis, probably representing the new species are not pyritized.

The material described here is housed at the Institute of Paleobiology, Polish Academy of Sciences, Warszawa. 


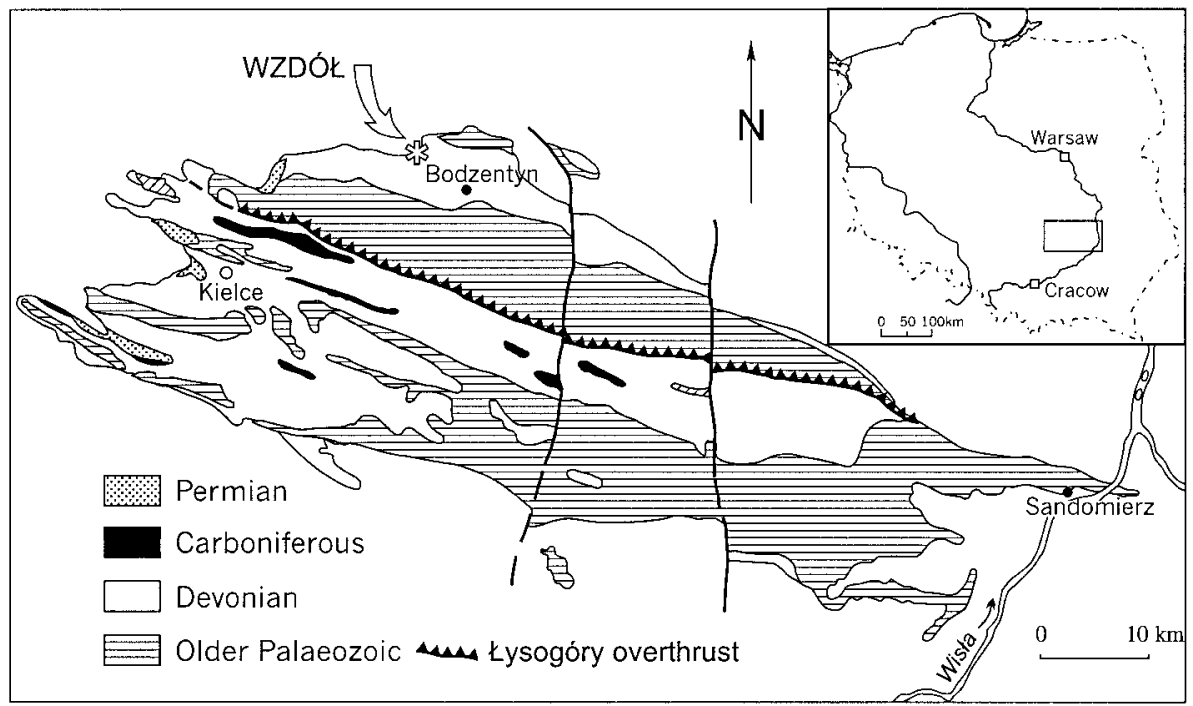

Fig. 1. Location of Wzdół Plebański section, at Ściegnia, near Bodzentyn, Holy Cross Mountains, Poland.

\section{SHELL STRUCTURE AND MODE OF PRESERVATION}

In thin sections the rhomboentomozoid Franklinella shows the same general type of shell structure as the entomozoids (Olempska, 1992; and in preparation). A very thin outer layer builds high projections forming the strong external ornamentation, largely in the form of flanges and ribs. There is a thicker, more complicated inner layer (the upper surface of which is visible when the outer layer has been exfoliated) that is covered by a 'secondary' ornamentation corresponding to the flanges and ribs of the outer layer. This ornamentation is weaker (e.g. peaks of ribs are usually rounded) than the external surface ornament of the valve. Mechanical preparation of the specimens usually results in the exfoliation of the thin outer layer together with the rock matrix. The inner layer is pyritized in the Franklinella material from Wzdół, with well preserved 'secondary' ornamentation on the upper surface; the thin outer layer is usually lost or only partly preserved (Pl. 1, fig. 2; Pl. 2, figs 1-4).

Pyritization of the shell is not a common phenomenon in the Devonian of the Holy Cross Mountains. The susceptibility of Franklinella to this mode of diagenetic alteration was possibly because the shell wall was rich in organic matter.

\section{SYSTEMATIC DESCRIPTION Superfamily Entomozoacea Přibyl, 1951}

Remarks. I continue to use the name Entomozoacea for the Palaeozoic so-called 'finger-print' ornamented myodocope ostracods, even though the Silurian type species of the group, Entomozoe tuberosa (Jones, 1861), probably belongs to Entomoconchacea Brady, 1868 and lacks the finger-print sculpture (Siveter \& Vannier 1990; Vannier \& Abe, 1992). Unlike other myodocopes, the Siluro-Devonian entomozoaceans lack a rostrum, rostral incisure or a siphon. However, an anteroventral indentation of the outline is developed in many genera.

Family Rhomboentomozoidae Gründel, 1962
Remarks. Wang $(1986,1989)$ reviewed current interpretations of the origin and evolution of the Rhomboentomozoidae, but the present knowledge of the Early Devonian rhomboentomozoid fauna remains superficial. The family is distinguished from the Entomozoidae Prribyl, 1951, by the generally triangular to subquadrate lateral outline and the long, straight dorsal margin. It includes Rhomboentomozoe Přibyl, 1951, Pseudoentomozoe Přibyl, 1951, Franklinella Stewart \& Hendrix, 1945, Paraungerella Wang, 1986 and Yulinentomozoe Wang, 1989.

Genus Franklinella Stewart \& Hendrix, 1945

Subgenus Franklinella (Franklinella) Stewart \& Hendrix, 1945 Type species. Franklinella novecosta Stewart \& Hendrix, 1945.

Remarks. The genus Franklinella was based on Franklinella novecosta Stewart \& Hendrix, 1945 from the Olentangy Shale, Franklin and Delaware counties, Ohio, USA. Sylvester-Bradley (1961) changed the name to Ungerella Livental, 1948 (type species Cypridina calcarata Richter, 1856), on the basis that Franklinella is preoccupied by a gastropod genus described by Nelson (1937). However, as noted by Gozalo \& Sánchez de Posada (1998, following the opinion of Helga GroosUffenorde), the name of the gastropod genus is unavailable according to the International Code of Zoological Nomenclature and, therefore, Franklinella Stewart \& Hendrix, 1945 remains the valid name.

\section{Franklinella (Franklinella) lysogorensis n. sp.} (Pls 1-3)

Derivation of name. From the Łysogóry Range, Holy Cross Mountains, Poland.

Diagnosis. Franklinella species with a well developed anteroventral spine and small posterodorsal spine. 20-25 longitudinal ribs are present in the adult tecnomorphs and about 35-38 ribs in the heteromorphs. Ribs gently curving dorsally in the anterior 


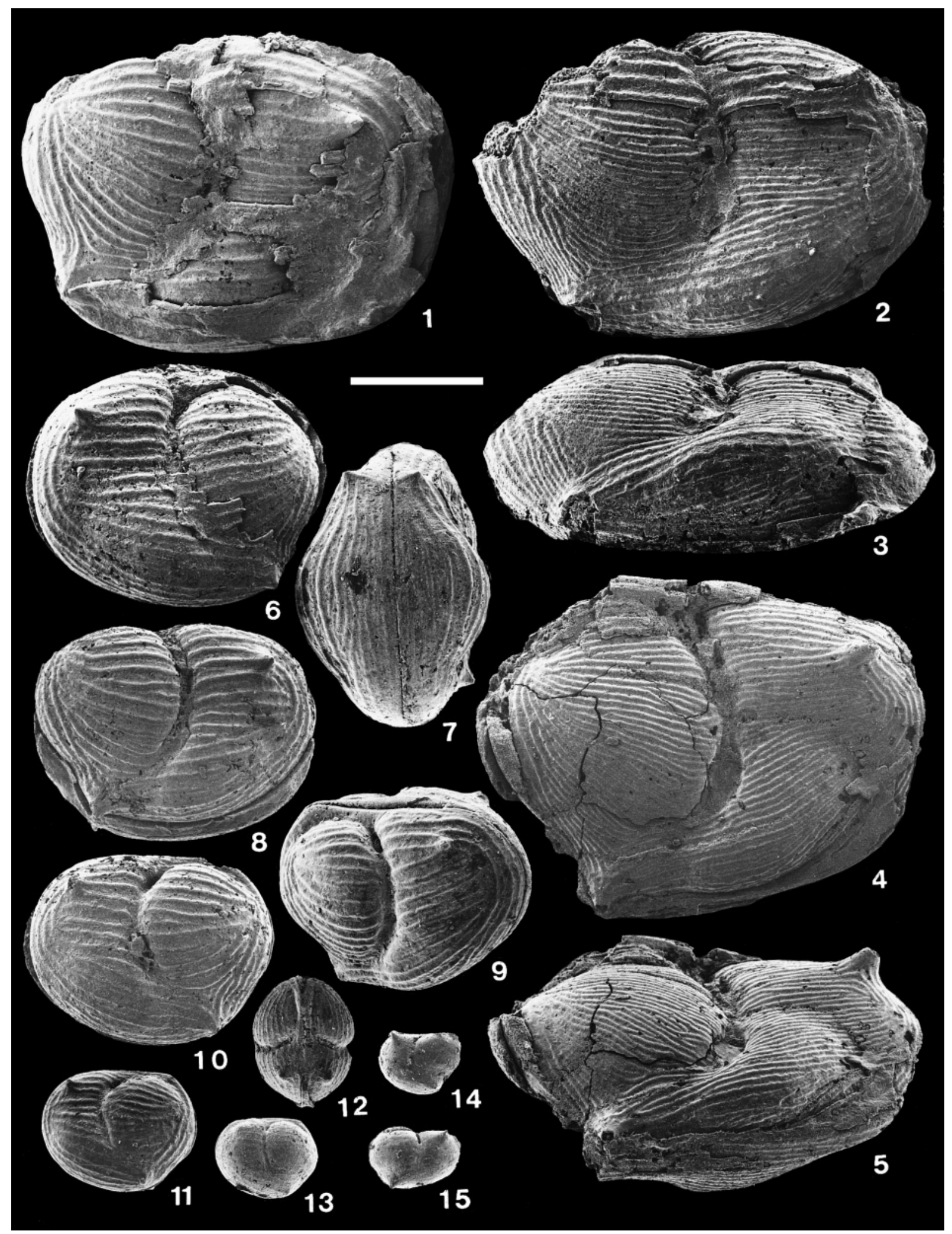

Explanation of Plate 1

Figs 1-15. Franklinella (Franklinella) lysogorensis n. sp. The ontogeny from instar A-6 to adult. Wzdół section, late Givetian-early Frasnian deposits, sample Wz R-Ic/2: 1, adult tecnomorphic carapace, left lateral view, ZPAL O.50/1; 2-3, heteromorphic left valve, (2) lateral view, (3) oblique view, ZPAL O.50/2; 4-5, heteromorphic left valve, holotype, (4) lateral view, (5) oblique view, ZPAL O.50/3; 6, juvenile carapace, right lateral view, ZPAL O.50/4; 7, juvenile carapace, ventral view, ZPAL O.50/5; 8, juvenile carapace, left lateral view, ZPAL O.50/6; 9, juvenile carapace, left lateral-oblique view, ZPAL O.50/7; 10, juvenile carapace, right lateral view, ZPAL O.50/8; 11, juvenile carapace, right lateral view, ZPAL O.50/9; 12, juvenile carapace, dorsal view, ZPAL O.50/10; 13, juvenile carapace, right lateral view, ZPAL O.50/11; 14, juvenile carapace, right lateral view, ZPAL O.50/12; 15, juvenile carapace, left lateral view, ZPAL O.50/13. Scale bar $500 \mu \mathrm{m}$. 

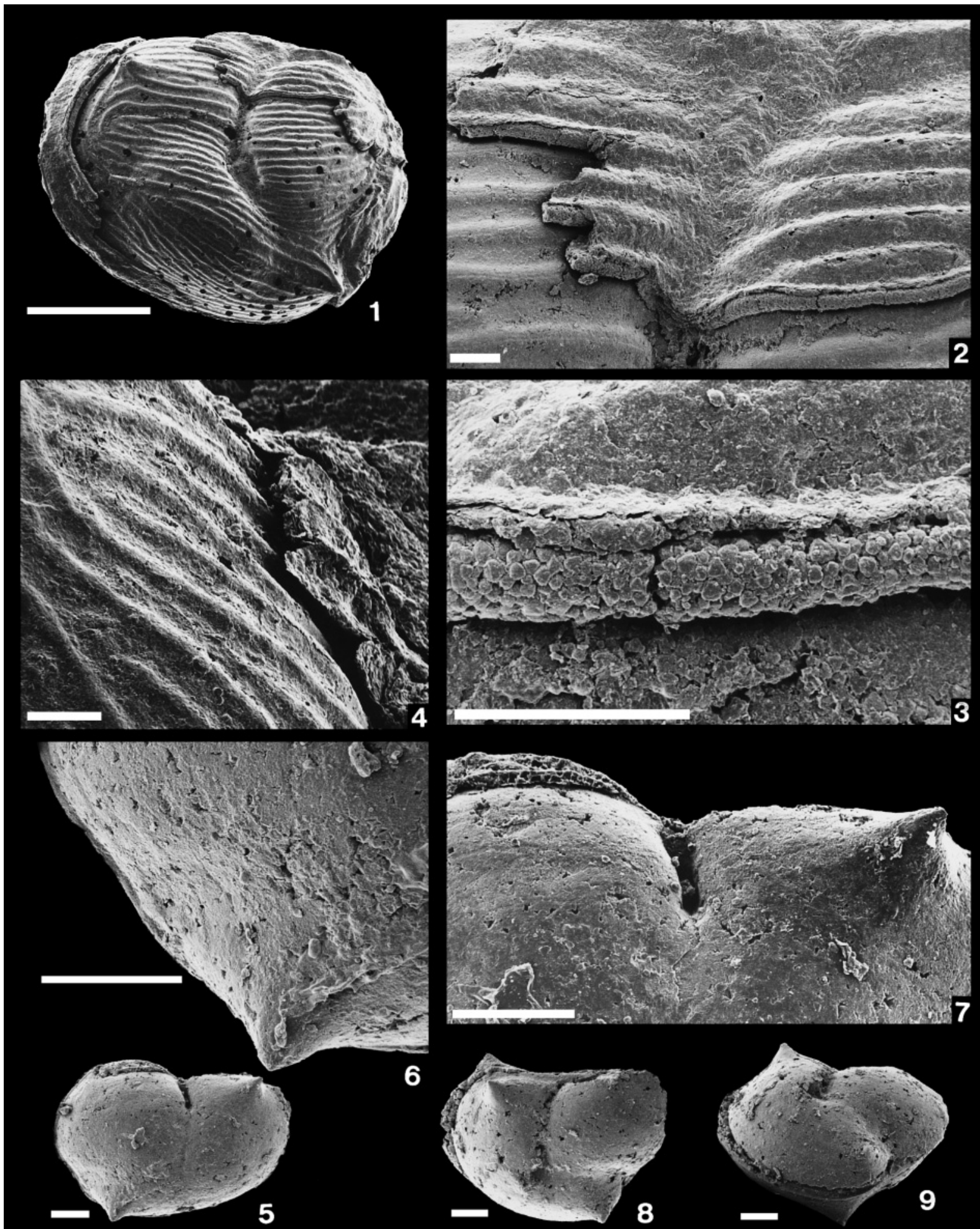

Explanation of Plate 2

Figs 1-9. Franklinella (Franklinella) lysogorensis n. sp. Shell structure. Wzdół section, late Givetian-early Frasnian deposits, sample Wz R-Ic/2: 1-3, heteromorphic right valve in lateral view, ZPAL O.50/14, (1) the outer layer partly preserved in dorsal part of carapace and upper surface of the inner layer is visible (scale bar $500 \mu \mathrm{m}$ ), (2-3) details of 1 , fragments of the outer layer visible; $\mathbf{4}$, fragments of the outer layer and upper surface of the inner layer visible, ZPAL O.50/17; 5-7, juvenile carapace in left lateral view, ZPAL O.50/13, (6) details of anteroventral part of carapace, (7) details of dorsal part of carapace; 8-9, juvenile carapace, ZPAL O.50/12, (8) right lateral view, (9) oblique ventral view. Figs $2-9$ scale bar $50 \mu \mathrm{m}$. 


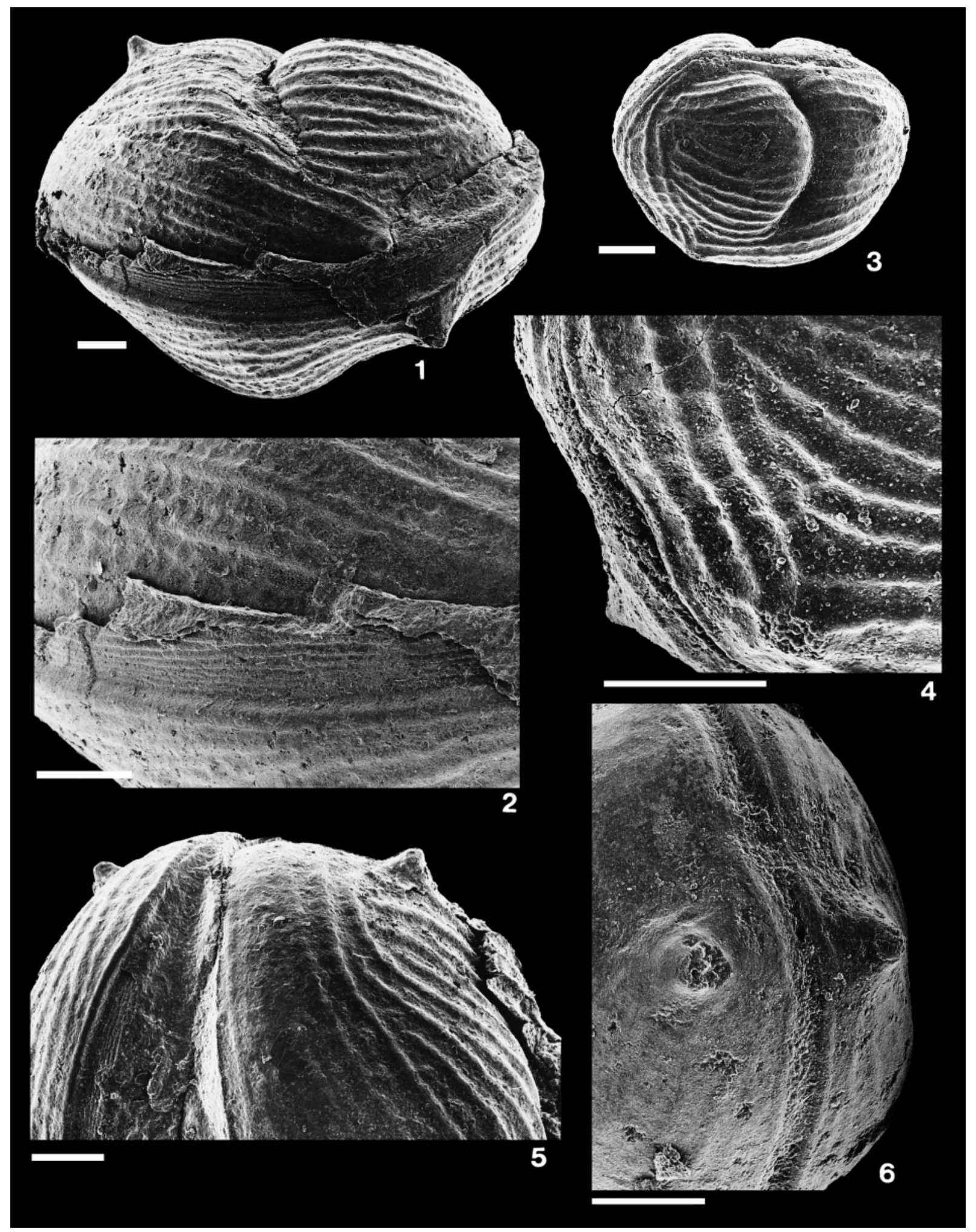

Explanation of Plate 3

Figs 1-6. Franklinella (Franklinella) lysogorensis n. sp. Wzdół section, late Givetian-early Frasnian deposits, sample Wz R-Ic/2: 1-2, tecnomorphic carapace in oblique ventral view, ZPAL O.50/15, (2) details of contact list with striate ornament; 3-4, juvenile carapace, ZPAL O.50/16, (3) oblique left lateral view, (4) details of anteroventral indentation; 5, half open carapace in posterior view, striated contact list visible in left valve, ZPAL O.50/17; 6, juvenile carapace in oblique anterior view, anteroventral indentation visible, ZPAL O.50/18. Scale bar $100 \mu \mathrm{m}$. 
part of the carapace. Two concentric outer ribs are parallel to the dorsal, anterior and posterior margins. Sulcus narrow and long with deep pit in its dorsal part, ribs more or less at right angle with sulcus. Posteroventral lobe distinct. Valve outline has an anteroventral indentation.

Holotype. Carapace ZPAL O.50/3 (Pl. 1, figs 4-5).

Material. 200 pyritized carapaces and 3500 of poorly preserved moulds.

Locality and horizon. Wzdół, Holy Cross Mountains, Poland. Devonian, Givetian/Frasnian transition beds.

Description. Carapace large (length up to $2 \mathrm{~mm}$ ), rounded subquadrate in lateral outline. The greatest length is slightly above mid-height. The greatest height is located in front of the sulcus. The greatest width is in the posteroventral part of the carapace. Posteroventral lobe present in adult valves, being larger in heteromorphs. Dorsal margin long and straight. Anterior cardinal angle is distinct, posterior cardinal angle is more broadly rounded. Ventral margin is convex; anterior margin rounded with a slight anteroventral indentation (Pl. 3, figs 4,6$)$; posterior margin evenly rounded. Valves are almost equal; right valve slightly larger and overlaps the left valve along the entire free margin. Contact list in the left valve is narrow, ornamented by very fine striation ( $\mathrm{Pl}$. 3, figs 1, 2, 5). Adductorial sulcus is long, deep, crescent-shaped, extends from dorsal margin just in front of mid-length, curved anteriorly and terminates just before anteroventral spine. Deep pit occurs in dorsal part of adductorial sulcus. In adult specimens, ventral part of sulcus is distinctly expanded. A short, conical spine occurs posterodorsally and a larger spine anteroventrally. The carapace surface has longitudinal ribs, up to 22 in adult tecnomorphs and about 35-38 in heteromorphs. In posterior part of carapace ribs run longitudinally, parallel to dorsal margin; in anterior part of carapace ribs are gently curved dorsally at their anterior ends. In additions two concentric admarginal ribs, parallel to margins, are present. There is no deviation of ribs across the sulcus. Internal morphology of valves unknown.

Remarks. The species is comparable to Franklinella (Franklinella) truyolsi Gozalo \& Sánchez de Posada, 1998, from the late Givetian of the Cantabrian Mountains (Gozalo \& Sánchez de Posada 1998; pl. 1, figs 8-12), but differs in the ribbing pattern, especially in the anterodorsal part, and in the occurrence of densely ribbed heteromorphs. Franklinella (Franklinella) latesulcata (Paeckelmann, 1922) illustrated by Rabien (1954; pl. 1, fig. 4), from the early Frasnian of the Rhenish Slate Mts. is similar in ribbing pattern to adult tecnomorphs of $F$. $(F$.) lysogorensis, but differs in the lack of the dorsal pit, small anteroventral spine and in the lack of posteroventral lobe. Franklinella (Franklinella) multicostata Rabien, 1954, from the early Frasnian of the Rhenish Slate Mts (Rabien 1954; pl. 3, figs 22-23) is similar in its rib pattern to heteromorphs of $F$. $(F$.) lysogorensis, but differs in more elongate outline, the absence of posteroventral lobe and narrow ventral part of sulcus. $F$. $(F$.) latesulcata and $F$. $(F$.) multicostata possibly represents sexual dimorphs.

The anteroventral indentation present in $F$. $(F$.) lysogorensis, and in several species of different genera of entomozoids, such as Maternella, Entomoprimitia and Nehdentomis, probably had a similar function to the rostral incision in typical myodocopids. In slightly open carapaces it probably made a slit-like opening through which the antennules could emerge; however, in closed carapaces this opening is not visible ( $\mathrm{Pl}$. 3, fig. 6). A similar anteroventral indentation occurs in the Silurian Entomis tuberosa (see Siveter \& Vannier, 1990).

The rhomboentomozoid spines are similar in position and probably function to the spines of the Recent thaumatocyprids. They probably prevented rotation of the carapace during swimming (Gooday, 1973).

\section{ONTOGENY AND DIMORPHISM}

Franklinella $(F$.) lysogorensis is represented by numerous juvenile and adult forms. Measurements of 164 specimens from one sample (Wz R-Ic/2) indicates (Fig. 2), that $F$. (F.) lysogorensis developed through at least seven ontogenetic stages. The instars do not form very distinct size classes; there is overlap in their size frequency distribution, especially in small instars.

Larval characters. Most features of the ornament develop gradually during ontogeny. The smallest specimens observed probably belong to instar A-6. They are about $0.25 \mathrm{~mm}$ long and $0.20 \mathrm{~mm}$ high, their ornament is poorly preserved ( $\mathrm{Pl}$. 2, figs 5-9), but the anteroventral indentation is visible (Pl. 2, fig. 6), and the adductorial sulcus is short and deep, reaching about $1 / 4$ of valve height. In subsequent instars the sulcus is relatively longer. Posterodorsal and anteroventral spines are well developed, even in the smallest specimens.

The relative depth of the dorsal pit is greatest in small instars and gradually decreases in subsequent instars; in adult specimens it is poorly visible. In adults the ventral part of the sulcus is wider, with a smooth oval area inside.

Ontogenetic development of dimorphism. The ornamentation of $F$. (F.) lysogorensis develops gradually during ontogeny, to the pre-adult instar. The ornamentation in the early instars consists of about 7-8 main longitudinal ribs, some additional ribs and 2 marginal concentric ribs. The number of main ribs gradually increases to about 20-22 in some adult specimens. These specimens probably represent tecnomorphs. The feature which most characteristically differentiates the sexes is the number of ribs in the heteromorphic shells. Some adults have 35-38 densely spaced main longitudinal ribs; these specimens are taken to represent heteromorphic valves (1.6-2.05 mm long). In heteromorphic valves the posteroventral lobe is also better developed than in tecnomorphic valves and carapaces of adult tecnomorphs are slightly shorter than those of heteromorphs. The material studied shows the presence of heteromorphs only in last instar (sample Wz R-Ic/2 contains 10 heteromorphic and 21 adult tecnomorphic specimens; Fig. 2), and this indicate that coarsely ribbed and densely ribbed forms are not distinct species. 


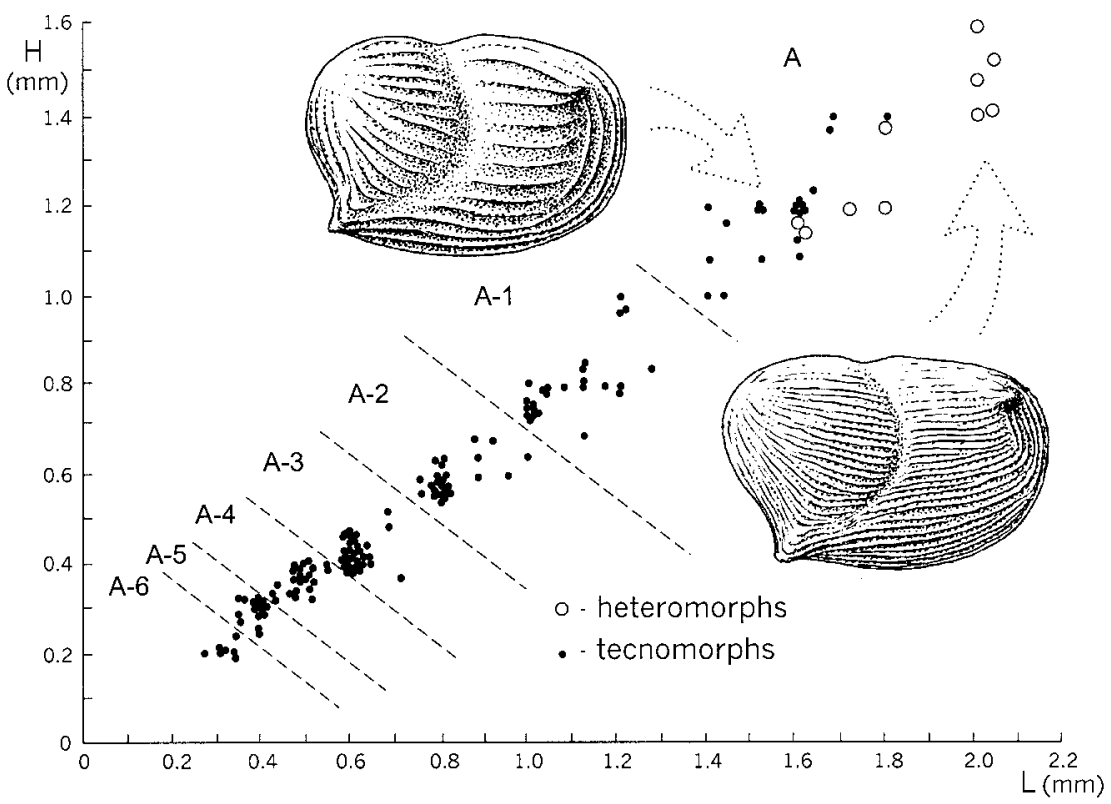

Fig. 2. Size distribution (height/length) for Franklinella (Franklinella) lysogorensis n. sp. All specimens are from a single sample from Wzdół section, late Givetian-early Frasnian deposits (sample Wz R-Ic/2).

\section{DISCUSSION}

Only a few quantitative investigations on the moult stages of entomozoid and rhomboentomozoid species have been undertaken (Rabien, 1954; Gooday, 1973; Gozalo, 1994). Franklinella (F.) lysogorensis seems to possess a dimorphism very similar to that described (Gozalo, 1994) in Franklinella (Arnoldella) trispinosa.

The presence of dimorphs with different ribbing pattern, as in $F$. (F.) lysogorensis and $F$. (A.) trispinosa, might have serious taxonomic consequences. It is possible that such dimorphs were previously attributed to separate species. This may apply to some poorly preserved Franklinella species, identified (MüllerSteffen, 1964) from the earliest Famennian from the Harz Mountains (early Nehden-Stufe, tnu) as Franklinella $(F$.) sigmoidale Müller-Steffen, 1964 and Franklinella (F.) fasciculata Müller-Steffen, 1964, which differ only in density of ribbing. Similar differences within the ribbing pattern were reported (Raith, 1968) from $F$. (F.) aff. sigmoidale and $F$. (F.) aff. fasciculata from the early Famennian (Nehden-Hemberg Stufe), and also (Rabien, 1954) from $F$. (F.) latesulcata and $F$. (F.) multicostata from the early Frasnian (Adorf Stufe, tau 1) of the Rhenish Slate Mts.

Thus, there is a need to taxonomically revise most of the Franklinella species. Unfortunately, many of the older descriptions and especially the incomplete original illustrations of entomozoaceans will not easily enable such a revision.

It is generally accepted that the dimorphism in ostracods is associated with reproduction. Another possible explanation was proposed by Triebel (1941) who suggested that dimorphism was the result of an ecological disparity between morphs and, indeed, according to Martinsson (1956) the sexes of some Palaeozoic ostracod species may have inhabited different biotopes. It has also been generally supposed that the dimorphs which differ from the larval instars in the shape and development of cruminal or dolonal pouches are females. It is difficult to decide whether the Franklinella type of dimorphism is connected with brood care, or associated with differences in mode of life or habitat.

The presence of two dimorphs with different types of ornamentation may occur in other entomozoacean species. For example, in some specimens of Maternella dichotoma, normal inner ribbing may be replaced by very fine, closely spaced ribs (see Gooday, 1973). There are also a lot of specimens among the Richterina (Richterina) striatula and Richterina (Richterina) tenuistriata groups that differ in the density of the ribbing pattern.

\section{CONCLUSIONS}

The data available indicate the presence of two types of sexual dimorphism within the superfamily Entomozoacea: domiciliar as in entomoprimitiids and ornamental as in rhomboentomozoids types. The ornamental type of dimorphism may also be represented in the true entomozoids, but more research on the nature of sexual dimorphism in the entomozoaceans is needed to confirm this.

The rhomboentomozoids share with the entomozoids a shell composition rich in organic material.

\section{ACKNOWLEDGEMENTS}

I thank Professor Grzegorz Racki (Department of Earth Science, Silesian University, Sosnowiec, Poland) for the material he placed at my disposal. All fossils described herein were collected by Prof. Racki during his field work, financed by the State Committee for Scientific Research, Poland (Project no. PO4D 02413 to Grzegorz Racki). Dr David Siveter and two anonymous reviewers are thanked for their help, advice and constructive review on a draft of the manuscript.

\section{Manuscript received 16 April 2000 \\ Manuscript accepted 10 December 2001}




\section{REFERENCES}

Becker, G. \& Bless, M.J.M. 1990. Biotope indicative features in Palaeozoic ostracods: a global phenomenon. In Whatley, R. \& Maybury, C. (Eds), Ostracoda and Global Events, 421-436. British Micropalaeontological Society Publication Series, Chapman \& Hall, London.

Bless, M.J.M., Crasquin, S., Groos-Uffenorde, H. \& Lethiers, F. 1986. Late Devonian to Dinantian ostracodes (comments on taxonomy, stratigraphy and paleoecology). Annales de la Societé Géologique de Belgique, 109: 1-8.

Casier, J.-G. 1987. Étude biostratigraphique et paléoécologique des ostracodes du recif de Marbre Rouge du Hautmont á Vodelée (partie supérieure du Frasnien, Bassin de Dinant, Belgique). Revue de Paléobiologie, 6: 193-204.

Gooday, A. 1973. Taxonomie and stratigraphic studies on Upper Devonian and Lower Carboniferous Entomozoidae and Rhomboentomozoidae (Ostracoda, ?Myodocopida) from Southwest England. PhD thesis, University of Exeter 1-260.

Gooday, A. 1983. Entomozoacean ostracods from the Lower Carboniferous of South-Western England. Palaeontology, 26: 755-788.

Gozalo, R. 1994. Geologia y Paleontologia (ostracodos) del Devónico Superior de Tabuenca (NE de la cadena Ibérica Oriental). Memorias del Museo Paleotológico de la Universidad de Zaragoza, 6: 1-291.

Gozalo, R. \& Sánchez de Posada, L.C. 1998. El género Franklinella (Ostracoda) en la sección de Collado de Polentinos (Devónico del Dominio Palentino, Cordillera Cantábrica). Revista Espanola de Paleontologia, 13: 235-242.

Lethiers, F. \& Whatley, R. 1994. The use of Ostracoda to reconstruct the oxygen levels of Late Palaeozoic oceans. Marine Micropaleontology, 24: 57-69.

Martinsson, A. 1956. Ontogeny and development of dimorphism in some Silurian ostracodes. Bulletin of the Geological Institutions of Uppsala, 37: 1-42.

Müller-Steffen, K. 1964. Neue oberdevonische Ostracoden (Familia Entomozoidae) aus dem Oberharz. Neues Jahrbuch für Geologie und Paläontologie, Abhandlungen, 119: 157-171.

Nelson, L.A. 1937. Gastropoda from the Pennsylvanian (Magdalena) of the Franklin Mountains of West Texas (abstract of PhD Thesis). The University of Colorado Studies, 25: 89-91.

Olempska, E. 1992. Shell structure of the entomozoaceans: allegedly planktonic ostracodes of the Palaeozoic. Acta Palaeontologica Polonica, 36: 373-398.

Olempska, E. 1997. Changes in benthic ostracod assemblages across the Devonian-Carboniferous boundary in the Holy Cross Mountains, Poland. Acta Palaeontologica Polonica, 42: 291-332.

Olempska, E. 1998. Ontogeny and sexual dimorphism in Ungerella (Rhomboentomozoidae). In Crasquin-Soleau, S., Braccini, E. \& Lethiers, F. (Eds), What about Ostracoda!, Actes du 3e Congrès
Europèen des Ostracodologistes, Paris-Bierville, France, 8-12 Juillet. Bulletin des Centres de Recherches Elf Exploration-Production, Mèmoire, 20: 420-421.

Orlov, A.N. 1996. Sex dimorphism of subfamily Entomoprimitiinae Gründel, 1962. 3rd European Ostracodologists Meeting, Paris-Berville, Abstracts 58-59.

Paeckelmann, W. 1913. Das Oberdevon des Bergischen Landes. Abhandlungen der Preussischen Geologischen Landesanstalt, Neue Folge, 70: 1-356.

Rabien, A. 1954. Zur Taxionomie und Chronologie der Oberdevonischen Ostracoden. Abhandlungen des Hessischen Landesamtes für Bodenforschung, 9: 1-268.

Rabien, A. 1956. Die stratigraphische Bedeutung der oberdevonischen Ostracoden. Zeitschrift der Deutschen Geologischen Gesellschaft, 106: 217-226.

Raith, M. 1968. Vorläufige Mitteilung über Ungerella-Formen (Ostracoda) aus der Nehden-Stufe (Oberdevon) des Schaumbergprofils bei Östrich im Sauerland (Rheinisches Schiefergebirge). Neues Jahrbuch für Geologie und Paläontologie, Monatshefte, 8: 481-495.

Richter, R. 1869. Devonische Entomostracen in Thüringen. Zeitschrift der Deutschen Geologischen Gesellschaft, 21: 757-776.

Rzehak, A. 1881. Oberdevonische Fossilien in der Umgebung von Bruenn. Verhandlungen der Kaiserlichen und Koeniglichen Geologischen Reichsanstalt, 16: 314-315.

Siveter, D. \& Vannier, J. 1990. The Silurian myodocope ostracode Entomozoe from the Pentland Hills, Scotland: its taxonomic, ecological and phylogenetic significance and the affinity of the bolbozoid myodocopes. Transactions of the Royal Society of Edinburgh: Earth Sciences, 81: 45-67.

Stewart, G.A. \& Hendrix, W.E. 1945. Ostracoda of the Olentangy shale, Franklin and Delaware counties, Ohio. Journal of Paleontology, 19: 96-115.

Sylvester- Bradley, P.C. 1961. Order Myodocopida Sars 1866. In Moore, R.C. (Ed.), Treatise on Invertebrate Paleontology, Q, Arthropoda 3. Geological Society of America, Lawrence, 387-406.

Triebel, E. 1941. Zur Morphologie und Ökologie der fossilen Ostracoden. Senckenbergiana, 23: 294-400.

Vannier, J. \& Abe, K. 1992. Recent and Early Palaeozoic myodocope ostracodes: functional morphology, phylogeny, distribution and lifestyles. Palaeontology, 35: 485-517.

Wang, Shang-qi 1986. Devonian Rhomboentomozoinae (Ostracoda) from Guangxi (in Chinese). Acta Palaeontologica Sinica, 25: 155-168.

Wang, Shang-qi 1989. Early Devonian ostracodes from Zhangmu of Yulin, Guangxi (in Chinese). Acta Paleontologica Sinica, 28: 249-268.

Warshauer, S.M. \& Duffield, S.L. 1983. The paleoecology of Devonian entomozoid ostracodes in the subsurface of the Appalachian Basin. VII International Symposium on Ostracoda, Beograd 1979. Additional Communications and Discussions. Serbian Geological Society 157-161. 